\title{
The Judicial Review Of Deed Creation And Validation Process Of Limited Liability Company On Ahu-Online Application System
}

\author{
Antonia Irawan', Fakhrul Wildan² and Setyawati
}

Abstract. The purpose of this study are to: 1) To Detect and deploy Analyzing the Accuracy and Validation Process Limited liability company Incorporation in AHUOnline system. 2) To Know and Analyzing Barriers happened and find solutions to overcome barriers Proper case Barriers to AHU-Online System in the Process of Approval of a limited liability company (PT). The data used in this research is secondary data, which includes Legal Materials Primary, Secondary and Materials Legal Materials Tertiary Law to support the assessment which is then analyzed by Empirical Juridical approaches do with the fact that there in Practice In the field. This approach is also known by the Sociological approach made directly to the field.

From the results of data analysis concluded that: 1) Accuracy and Validation Implementation in the Process of Establishment of a Limited liability company in AHU-Online system, according to the provisions of Article 9 UUPT that in order to obtain a Ministerial Decree on Approval of the Company Law Board, submitted through Online by Electronic AHU to the Minister. 2) Obstacles and Solutions in case the system is AHU-Online in the Process Ratification of a limited liability company, if it is proven the person doing the transaction was not competent law to conduct a transaction and a violation of the requirements of a particular case, and Abuse Terms of a For Halal, the Treaty of Establishment of Company can be canceled. In case of violation of the contents of the Agreement Establishing a company, it can do some act of law. If arises a problem of law and based on the Article 16 Paragraph (1) of Act No. 48 Of 2009 concerning Judicial Authority, that the court may not refuse to Check, Passing and Terminate and Judges shall Digging, Following and Understanding the Values of Law and Sense of Justice living in the community.

Keywords: Judicial Review; Limited Liability Company; AHU-Online.

\section{Introduction}

Form a limited liability company is a company in which capital is divided into shares, and the responsibility of the shareholders of the Limited Liability Company is based on the Number of Shares he owns. As for tools or equipment from the Organization Limited Liability Company, such as the Board of Directors, Comisaris and General Meeting of Shareholders (AGM). To know the ins and outs of Juridical from a Limited Liability Company, it needs to be known with certainty about the Basic Law of Limited Liability Company. Legal Basis Limited Liability Company. Regarding the provisions of

\footnotetext{
1 Students of Master of Law, Faculty Of Law, Universitas Islam Sultan Agung and an Entrepreneur e-mail: antoniairawan@gmail.com

2 Students of Master of Law, Faculty Of Law, Universitas Islam Sultan Agung email fakhrul.wildan@gmail.com
} 
law applicable to the Company under Article 4 of Act No. 40 of 2007 (Company Law), ${ }^{3}$ which reads:

"Against the Company applies this Act, the Articles of Association of the Company, and the provisions of Laws and Regulations".

Based on the third paragraph of Article 4 Explanation of the Company Law Company Law "More Superior" (PREVAIL) of the Articles of Association (AD). Therefore, the provisions of the AD should not conflict with the Company Law of 2007, it will apply the Company Law of 2007. ${ }^{4}$

The term "Corporate" (PT) consists of two (2) words, namely "Company" and "Limited". "Company" refers to the Capital PT consisting of "Sero-sero" or "shares". As for the word "Limited" refers to the responsibility of shareholders only limited to the nominal value of all shares owned. Rationale that PT's capital consists of "Sero-sero" or shares "can be seen in the provisions of Article 1 point 1 Act No. 40 of 2007 namely:

"Limited Liability Company, hereinafter referred to as the Company is the legal entity which is a Capital Alliance, established by the Treaty, conduct business activities with authorized capital divided into shares entirely, and meet the requirements set forth in this Law and Regulation The exercise". ${ }^{5}$

The designation "limited responsibility" Shareholders can be seen from Act No. 40 of 2007 which reads: "Shareholders of the Company is not responsible in Person on Commitments made in the name of the Company and is not responsible for Losses the Company exceeded its existing Shares Value" ${ }^{6}$

In Article 1 Act No. 40 of 2007 it is clear that the Limited Liability Company or PT is Body Law that was established based on the "Agreement". Because the "Agreement" then there are those who make Agreement mentioned that that is to say there is more from one or are at least two (2) or two (2) parties to the agreement, as mentioned in Article 1313 Book of Civil Law. ${ }^{7}$

The Company Law Board itself is basically a Body to Have Rights and obligations to perform acts such as Human, Intellectual Had Myself, and sued before the Court. The Company Law Board approved by the Minister, Ratification of the Minister as specified in Act No. 40 of 2007 which states as follows: "The Company obtained legal entity status on the date of issuance of Ministerial Decree on Approval of the Company Law Board". 8

In carrying out His post Notary addition to making the Deed of Establishment of a Limited Liability Company and also Acts Amendment of Articles of Association and / or Data Company, a notary is also a Power of Attorney for Applying for Approval of Legal Entity Limited Liability Company, for Approval of Amendment of Articles of Association and also Submission of Application Notification Amendments to the Articles of Association and or Data Limited Liability Company at the Ministry of Justice and Human Rights of the Republic of Indonesia through the Media applying online, the Legal Entity Administration System (SABH) accessed through AHU-Online. In the execution of the

3 M. Yahya Harahap, 2019, Hukum Perseroan Terbatas, Sinar Grfika, Cetakan Ketujuh, Jakarta, p 83.

4 Ibid. p. 86.

${ }^{5}$ Article 3 Act No. 40 of 2007 on Limited Liability Company

${ }^{6}$ Article 1 (1), Act No. 40 of 2007 on Limited Liability Company

7 I.G. Rai Wijaya, 2000, Hukum Perusahaan, Cet.2, Kesaint Blanc, Bekasi, p. 134.

${ }^{8}$ Article 7 (4), No. 402007 on Limited Liability Company 
Notary shall Careful and Thorough in entering data in AHU-Online, especially at the time of Registration Limited Liability Company (PT). Transaction process electronic data as well as AHU-Online applications must be considered Aspect Requirements Possible Closed statute because there will arise a dispute.

Based on these descriptions, the writer interested to do more research will be manifested in a study entitled: "The Judicial Review Of Deed Creation And Validation Process Of Limited Liability Company On AHU-Online Application System".

\section{Research methods}

The method used in this study is primarily Juridical Empirical Approach. The Empirical Approach Juridical done field research is the fact that in practice In the field. This approach is also known by the Sociological approach that is closer to the people through the application of Law and Social Sciences Discussion linkages with the Law itself in order to complete the Legal Problems. ${ }^{9}$

\section{Results and Discussion}

\subsection{Validity of Endorsement Limited Liability Company In SABH Through AHU-Online}

The Company was formed by an agreement under which an agreement there must be a minimum of two (2) or more persons bind himself and forth in a deed of Notary Authentic and made in Indonesia. In accordance with the provisions of Article 27 paragraph (1) in Act No. 40 of 2007, so that the Agreement to Establish the Company's legal according to the laws founder least two (2) "Person" or more. ${ }^{10}$

Then the Company must be made in a Deed of Authentic or Deed, so all things are created by the parties to the agreement to establish a company must Authentic and should not be made Under hand, must be made by the General Authorities, and must be in Indonesian is not the language other countries-languages, but not necessarily be translated into other languages.

Once these things are fulfilled then the next step is the submission of Request Validation For Legal Entity to the Ministry of Justice and Human Rights of the Republic of Indonesia through the SABH which is in the process of Computerized System Validation through the establishment of a Legal Entity website of AHU-Online.

In Article 9 paragraph (2) Act No. 40 of 2007 on Limited Liability Company determined that the Endorsement is given within 60 (sixty days) after the application is received. The purpose of this statement is that the Application must be received by the officials concerned in this case the Ministry of Justice and Human Rights of the Republic of Indonesia and are already qualified and completeness required.

Furthermore, in the Act No. 40 Of 2007 on Limited Liability Company does not explain about how Procedures or procedures to be carried out in the framework of Appeals Process Request announcement that the Company's Legal Entity on DG AHU as

${ }^{9}$ Esmi Warassih et al., 2016, Penelitian Hukum Inter Disipliner, Thafa Media, First Pub., Yogyakarta, p.106.

${ }^{10}$ M. Yahya Harahap, 2019, Pembahasan Permasalahan Dan Penerapan KUHP Penyidikan dan Penuntutan, Sinar Grfika Cetakan Ketujuh, Jakarta, p 35. 
mentioned in Article 22 paragraph (3) Act No. 40 of 2007 on Limited Liability Company that announcement Application Procedures performed in accordance with the legislation in force.

Based on the Regulation of the Minister of Justice and Human Rights of the Republic of Indonesia Number 4 of 2014 on the Procedures for Submission of Application And Approval of Legal Entities And Submission amendments of such Amendment Notice and Data Changes Limited Liability Company, and Regulation of the Minister of Justice and Human Rights issued Regulation No. Menkumham 1 Of 2016 on the Amendment of the Minister of Law and Human Rights No. 4 of 2014 About Procedure for Approval of Legal Entities and amendments of the Agreement as well as the submission of such Amendment Notice and Change Data Company. In principle govern the latest way to improve the service and Accelerate the Process Validation Law Firm, Approval of Amendment of Articles of Association, the Articles of Association Submission of Notice of Change, and Change Data Limited Liability Company through Electronic Media, then the application filing process through SABH Company Announcement to the announcement in the Official Gazette of the Republic of Indonesia ${ }^{11}$

which means that the Company has Legal Entity in full can be said to be valid throughout the process is running as it should be as set out in the Regulation of the Minister of Justice and Human Rights of the Republic of Indonesia Number 4 of 2014 on the Procedures for Filing Request Approval of Legal and Approval of Amendment of Articles of Association And Submission notifications such Amendment and Change Data Limited Liability Company and the Director, as the process has got Legalization or guaranteed by the authorities in this case the Ministry of Justice and Human Rights of the Republic of Indonesia and has had a Legal Binding Strength of the party.

By using SABH no problems in practice into a Limited Liability Company Legalization Law Firm because this system has a control function and a good control, thus reducing human error because the whole process to automatic system.

\subsection{Problem Laws That Occur In Limited Liability Company Endorsement In SABH Through AHU-Online}

Ratification Process of the Company Law Board in SABH through internet facilities conducted by the Notary Public Notary where sufficient access SABH through AHUOnline Application in order to carry out the process of registration of the Company into a legal entity can cause a variety of legal issues. Legal Issues that may arise in this process, such as Legal requirements that must be met in the process of Ratification of Legal Entities in Electronics, fulfillment factor Accuracy and Validation and Legal Requirements in every Form Input Data Company, and includes also problems settlement and legal protection in case disputes in the process of Legal Liability Endorsement through the SABH.

In the Electronic Transactions as in SABH very difficult to determine a person whose conduct transactions and declares himself as a Notary if the person is competent to perform an Engagement, because the application process that occurs not directly done

${ }^{11}$ Article 1, Regulation of the Minister of Justice and Human Rights of the Republic of Indonesia Number 1 of 2016 on the Amendment Regulation of the Minister of Law and Human Rights No. 4 of 2014 About Procedure for Approval of Legal Entities and amendments of the Agreement as well as the submission of such Amendment Notice and Change Data Company. 
but through the Media Center are not visible to anyone who conduct such transactions, If proved, the person who does not Proficient Conducting Transactions Law to conduct a transaction, then the Agreement can be canceled. Agreements are considered valid if it meets the four (4) conditions regulated in Article 1320 of the Civil Code, which agreed they were bound themselves, Proficient to make an Engagement, a certain thing and a cause that is kosher. In terms of his legal requirement Proficient agreement to create an Engagement, basically everyone is capable to make Engagements, except pursuant to an Act is that they are not yet adults and those who are under the Assisted Living.

In the legal system, the existence of an archive is as Evidence that could explain the existence of certain information or in other words is as proof against the occurrence of an Event of Law who has certain legal consequences for the rights and obligations of the parties concerned. Likewise, the presence Electronic Archive, although it actually has some specific advantages fact can not be easily captured by the five senses so that the proof strength becomes weak.

Data in Electronic Transactions process as well as applications must be considered Aspect Requirements SABH statute because it is possible that there will be a dispute in the process that is difficult to resolve because the law requirements can not be met.

There are several requirements that must be met Law in the transaction or electronically process, namely: ${ }^{12} 1$ ) Authenticity, the parties involved in the Electronic Transactions must believe that the authenticity and the communication is received. Authenticity is needed in order to be used as a Means of Verification in court, 2) Integrity, $A$ recipient requires confidence in the integrity of the communication before acting to conduct transactions or certain that the message is not altered. These requirements are also required by law as a Means of Verification, 3) Can not Indisputably (Non-repudiation) became a legal requirement when the sender of a message can not deny that the sender of the message is never sent a message, 4) Written and Signature, the Law requires that the agreement must contain two things, the document written and signed. If the parties enter into a contract online, then the terms in writing and signed should be implemented, and 5) Confidentiality Confidentiality is necessary to protect the property rights to the information. Confidentiality is necessary to prevent access to and use of information that could cause harm to the owner information, such as bank account number.

In the Transaction Data Systems as well as a lot of debate about SABH electronic data such as e-mail used as a Means of Verification in Legal System. HIR in Article 164 and Article 1866 of the Civil Code regulates the Evidence that may be filed in the trial process, namely proof paper, witness evidence, suspicions-conjecture, Recognition and Oath. Based to the article, there is no rule that definitively confirms the electronic data. Legal issues that can arise in SABH process is related to the mechanisms of dispute resolution that may arise in this SABH process. Until now, the absence of a mechanism that is completely adequate in the system of justice in Indonesia. Therefore, the way that must be taken in finding Judicial Settlement if the occurrence of a dispute in the process SABH namely through the discovery of the Law by Judge it based on Act No. 14 of 1970 concerning Judicial Authority that a judge can not adjudicate on Case filed reasons that legislation which have turned out to unclear or incomplete, but the judge

\footnotetext{
${ }^{12}$ Budi Agus Riswandi, Hukum dan Internet di Indonesia, Yogyakarta: UII Press, 2003, p. 43-44,
} 
must still hear the Case filed and Judge as Law Enforcement and Justice shall Digging, Following and Understanding the values that live in the community law.

\section{Closing}

\subsection{Conclusion}

- Accuracy and Validation Implementation in the Process of Establishment of a Limited liability company in AHU-Online system, according to the provisions of Article 9 Act No. 40 Of 2007 regarding Limited Liability Company that in order to obtain a Ministerial Decree on Approval of the Company Law Board, Founder jointly file an application through the Information Technology Services Legal Entity Administration System or also known as Electronic SABH to the Minister.

Transparency or openness $\mathrm{SABH}$, see clearly the whole process of making the trip Establishment Decree Law. Objectives Administrating Process and Change Agency Establishment Law Indonesia, into a Bank Data (Database) that will Improve the Performance of the Ministry of Justice and Human Rights of the Republic of Indonesia, particularly the Directorate General of Administrative and General Services in the field of Law.

By using SABH no problems in practice into a Limited Liability Company Legalization Law Firm because this system has a control function and a good control, thus reducing human error because the whole process to Automatic;

In the Electronic Transactions as in SABH through AHU-Online is very difficult to determine a person whose conduct transactions and declares himself as a Notary if the person is competent to perform an engagement, because the application process that occurs not directly done but via the Internet that can not be seen by the conduct such transactions.

- Obstacles and Solutions in case the AHU Systems Online in the Process of Approval of a limited liability company, if it is proven that the person doing the transaction is incompetent law to conduct a transaction, then the Agreement can be canceled. In case of violation of the contents of the Agreement Establishing a company, it can do some legal action. Violation of terms agreement for their The mistake, of coercion or fraud and Terms skills, the legal action that can be done is to cancel the Agreement Establishing the Company's bank, the cancellation is made by the judge at the request of the Founder or a person under the Act is not yet capable of law, or can also by Founders under the Act is declared competent legal and allowed to express Founder incompetence that does not yet capable of the law as set forth in Article 1331 of the Civil Code. While in case of violation of these terms a particular case, as well as an infringement because the Halal requirement, then the Agreement Establishing the Cancel by Company Law, the original meaning of the Treaty has never been considered or had never been born an Engagement Agreement or on the establishment of the Company.

As a Legal Entity Law Company are subject independently responsible for any act of law that does regardless of the Founders or the holder of shares. It is expected the authorities to immediately establish and endorse legislation regulating the Cyber Law, especially in terms of the Engagement or by Electronic Agreements or through the Internet for the benefit of tackling the legal issues that may arise, so as to create legal certainty. If you develop a Legal Problems that occur when the 
Registration and Approval of the Company through $\mathrm{SABH}$, then based on the Article 16 Paragraph (1) of the Constitution Act No. 48 Of 2009 concerning Judicial Authority, that the court may not refuse to Check, Passing and Disconnecting a Case filed on the grounds that the law does not exist or is less clear, but is obliged to examine and hear, as well as Judge checking, Passing and Resolving Cases in the Court, based on the Article 28 Paragraph (1) of Act No. 48 Of 2009 on Judicial Power, that judge shall Digging, Following and Understanding Values Sense of Law and Justice who live in the community.

\subsection{Suggestion}

- System integration between Administration PNRI with the Directorate General of Law and Human Rights Ministry of Justice so that the announcement of PT in the Official Gazette is not too long.

- The existence of the perfect Integration between the Directorate General of Taxes and the Directorate General of Law Administration Ministry of Law and Human Rights so as not merely Publishing and Data Validation of Tax Index Number (NPWP/TIN) in PT, but also including TIN Data Validation for Managers and Shareholders can run perfectly.

- Directorate General of Legal Administration who has the authority in the field of services and Legalization Agency Limited Liability Company, it is necessary to perform housekeeping and Implement the things mandated by Act No. 40 of 2007 on Limited Liability Companies. It is expected that the Civil Directorate, Directorate General of Legal Administration did simplification Content Articles of Association of Limited Liability Company, Simplify Simplify Procedures and Requirements Validation Legal Entity Limited Liability Company.

\section{References}

[1] Budi Agus Riswandi, 2003, Hukum dan Internet di Indonesia, UII Press, Yogyakarta.

[2] Esmi Warassih et al., 2016, Penelitian Hukum Inter Disipliner, Thafa Media, Cet. Pertama, Yogyakarta, hal.106.

[3] I.G. Rai Wijaya, 2006, Hukum Perusahaan, Kesaint Blanc, Cetakan Kedua, Bekasi.

[4] M. Yahya Harahap, 2019, Hukum Perseroan Terbatas, Sinar Grfika Cetakan Ketujuh, Jakarta.

[5] Act No. 40 of 2007 on Limited Liability Company,

[6] Act No. 2 Of 2014 on Limited Liability Company,

[7] Regulation of the Minister of Justice and Human Rights of the Republic of Indonesia Number M.HH-03.AH.01.01 The of 2009 About the Company Register;

[8] Regulation of the Minister of Justice and Human Rights of the Republic of Indonesia Number M.HH-02.AH.01.01 The of 2010 About Procedure Limited liability company Announcement In State Gazette and the Official Gazette of the Republic of Indonesia;

[9] Regulation of the Minister of Justice and Human Rights of the Republic of Indonesia Number 1 Of 2016 on the Amendment Regulation of the Minister of Law and Human Rights No. 4 of 2014 About Procedure for Approval of Legal 
Entities and amendments of the Agreement as well as the submission of such Amendment Notice and Change Data Company.

[10] Renvoi Journal, No. 24, May-June 2005, p. 34.

[11] http://panduan.ahu.go.id/doku.php?id=perseroan terbatas, Accessed June 21, $\underline{2019}$ 